\title{
KONSTRUKSI REALITAS SIARAN BERITA PADA TELEVISI LOKAL
}

\author{
Noneng Sumiaty \\ Balai Pengkajian dan Pengembangan Komunikasi dan Informatika (BPPKI) Bandung J1. Pajajaran no. 88 Bandung, \\ Jawa Barat-40173. Telp.(022)6017493, Fax. (022) 6021740, HP. 08122303764. Email: nsumiaty62@ gmail.com

\section{Neti Sumiati} \\ Balai Pengkajian dan Pengembangan Komunikasi dan Informatika (BPPKI) Bandung Jl. Pajajaran no. 88 Bandung, \\ Jawa Barat-40173. Telp.(022)6017493, Fax. (022) 6021740, HP. 0811220846. Email: hanetihasan@ gmail.com \\ Naskah diterima tanggal 6 Maret 2015, direvisi tanggal 26 Mei 2015, disetujui tanggal 22 Juni 2015
}

\section{REALITY CONSTRUCTION OF NEWS RELEASE ON LOCAL TELEVISION}

\begin{abstract}
The research generally aims to know the reality of journalists and television media in local television news. This is a descriptive study through a qualitative approach. Techniques of data collection are done through observation, in-depth interviews with key informants (key person), which is leading people in the editorial, the coordinator of the coverage, presenter of news, finance and human resource development and master of ceremony room ATV Sukabumi. The survey results revealed that to serve a local television news required reporting from journalists. Before the news broadcast gets edit of journalists, the coordinator of the coverage and the editor in chief as the elaboration of filtering journalist and chief editor of coverage as the owner of a local television media. So that, a local television news broadcast can not avoid the subjective element of the journalists and media owners who are part of the construction.
\end{abstract}

Keywords: construction, reality, news, local television, and digital.

\begin{abstract}
Abstrak
Penelitian "Konstruksi Realitas Siaran Berita Pada Televisi Lokal", secara umum bertujuan untuk mengetahui realitas jurnalis dan media televisi dalam pemberitaan televisi lokal. Penelitian ini bersifat deskriptif melalui pendekatan kualitatif. Teknik pengumpulan data dilakukan melalui observasi, wawancara mendalam kepada informan kunci (key person), yaitu pemimpin redaksi, koordinator liputan, presenter warta, finance dan human resource development dan master of ceremony room ATV Sukabumi. Hasil penelitian diketahui bahwa untuk menayangkan suatu berita di televisi lokal diperlukan peliputan dari wartawan atau jurnalis. Sebelum siaran berita disiarkan selalu mendapat edit dari wartawan sebagai peliput berita, koordinator liputan, dan pemimpin redaksi sebagai penjabaran dari filtering wartawan peliputan dan pimpinan redaksi sebagai pemilik media televisi lokal. Karena itu siaran berita televisi lokal tidak bisa terhindar dari unsur subjektif para jurnalis dan pemilik media yang merupakan bagian dari konstruksi.
\end{abstract}

Kata kunci: konstruksi, realitas, siaran berita, televisi lokal, dan digital. 


\section{PENDAHULUAN}

Sejak diundangkannya Undang Undang Nomor 32 Tahun 2002 tentang Penyiaran, penyiaran tidak lagi menjadi monopoli Pusat. Sebagai konsekuensinya lahir televisi lokal di berbagai daerah yang merupakan media penyiaran lokal dengan jangkauan terbatas pada wilayah dan target pemirsa lokal di tempat stasiun televisi lokal bersiaran.

Bermunculannya televisi lokal di berbagai daerah, merupakan angin segar bagi masyarakat sekitar untuk bisa menikmati sajian acara yang kental budaya lokalnya. Sejalan dengan kemajuan di bidang teknologi informasi, siaran televisi sangat berperan dalam ikut serta menyerdaskan bangsa, dan memberikan informasi serta menyajikan hiburan yang sehat. Salah satu acara yang ditayangkan oleh televisi lokal adalah pemberitaan/informasi, pendidikan, dan hiburan. Peran utama dari televisi lokal adalah untuk melestarikan budaya dan kearifan lokal dalam berbagai aspek kehidupan di wilayahnya.

Televisi lokal khususnya di Jawa Barat diharapkan mampu memberikan pilihan tontonan bagi masyarakat untuk memeroleh informasi, pendidikan, dan hiburan serta menemukan budaya lokalnya. Namun hal itu tidak mudah untuk diwujudkan, karena pendirian stasiun televisi lokal memerlukan berbagai sarana dan prasarana yang tidak sedikit, mulai dari modal yang besar, sumber daya manusia yang profesional dan terbatasnya chanel yang ada.

Jaringan telekomunikasi TIK sebagai salah satu infrastruktur pembangunan nasional memiliki peran yang vital dan strategis sehingga dapat mendorong pertumbuhan ekonomi, menyerdaskan kehidupan bangsa, memperkukuh persatuan dan kesatuan, serta mampu memperlancar tugas-tugas pemerintah.

Kontruksi realitas pada dasarnya adalah menceritakan, mengonseptualisasikan peristiwa, keadaan tertentu. Tiap aktor sosial berperan dalam proses konstruksi realitas ini, termasuk media televisi lokal. Lebih-lebih bila objek pemberitaan atau peristiwa yang terjadi adalah masalah yang kontroversial, dan menjadi ajang pemikiran/ideologi serta kelompok tertentu. Karena begitu banyak realitas, media harus melakukan proses filtering, mana yang akan ditampilkan dan mana yang tidak. Begitu juga dengan penayangan berita di televisi lokal, sebelum ditayangkan selalu di edit di bagian editor, mana yang akan ditampilkan dan mana yang tidak dapat ditampilkan. Setelah melalui pengeditan barulah berita itu ditampilkan di media televisi.

Berangkat dari hal tersebut di atas, maka fokus penelitian ini adalah: bagaimana televisi lokal mengonstruksi realitas pemberitaan daerah?. Tujuan penelitian ini untuk mendapatkan informasi tentang konstruksi realitas penyiaran oleh televisi lokal yang antara lain: untuk mengetahui realitas jurnalis dan media televisi dalam pemberitaan televisi lokal.

Penyelenggaraan penelitian ini diharapkan menjadi masukan berharga bagi pemerintah sebagai pembuat kebijakan, dalam hal ini Kementerian Komunikasi dan Informatika serta lembaga penyiaran baik pusat maupun daerah mengenai konstruksi realitas pemberitaan pada televisi lokal.

\section{LANDASAN KONSEP}

\section{Penelitian Terdahulu}

Penelitian ini berbeda dengan penelitian terdahulu, karena secara umum penelitian ini bertujuan untuk mengetahui realitas jurnalis dan media televisi dalam pemberitaan televisi lokal. Penelitiannya bersifat deskriptif melalui pendekatan kualitatif. Teknik pengumpulan data dilakukan melalui observasi, wawancara mendalam kepada informan kunci, yaitu pemimpin redaksi, koordinator liputan, presenter warta, finance dan human resource development, dan master of ceremony room Andallan Utama Televisi Sukabumi. Sementara hasil penelitian menunjukkan bahwa sebelum siaran berita ditayangkan selalu mendapat edit dari wartawan, 
koordinator liputan, dan pemimpin redaksi dalam penjabaran dari filtering wartawan peliputan dan pimpinan redaksi sebagai pemilik media televisi lokal. Karena itu siaran berita tidak bisa terhindarkan dari unsur subjektif para jurnalis dan pemilik media yang merupakan bagian dari konstruksi.

\section{Konstruksi}

Menurut Von Glasersfeld, pengertian konstruktif kognitif muncul pada abad ini, disebarkan oleh Jean Piaget. Namun apabila ditelusuri, gagasan-gagasan pokok konstruktivisme sebenarnya telah dimulai oleh Giambatissta Vico, seorang epistimolog dari Italia. Ia adalah cikal bakal kontruktivisme (Suparno, 1997 dalam Bungin, 2008).

Menurut Berger dan Luckmann dalam Hidayat (2003) proses mengonstruksi berlangsung melalui interaksi sosial yang dialektis dari tiga bentuk realitas, yakni symbolic reality, objective reality, dan subjective reality yang berlangsung dalam suatu proses dengan tiga simultan yakni eksternalisasi, objektivasi, dan internalisasi. Objective reality, merupakan suatu kompleksitas definisi realitas (termasuk ideologi dan keyakinan) serta rutinitas tindakan dan tingkah laku yang telah mapan terpola (tercakup di dalamnya adalah berbagai institusi sosial dalam pasar), yang kesemuanya dihayati oleh individu secara umum sebagai fakta. Symbolic reality, merupakan semua ekspresi simbolik dari apa yang dihayati sebagai objective reality, termasuk di dalamnya teks produk industri media, representasi pasar, kapitalisme, dan sebagainya dalam media. Sedangkan subjective reality merupakan konstruksi definisi realitas (dalam hal ini misalnya media, pasar, dan seterusnya) yang dimiliki individu dan dikonstruksi melalui proses internalisasi.

Teori dan pendekatan konstruksi sosial atas realitas Berger dan Luckmann telah direvisi dengan melihat variabel atau fenomena media massa menjadi sangat substansi dalam proses eksternalisasi, subjektifikasi, dan internalisasi. Dengan

\section{Penelitian Terdahulu}

No/Judul/ Nama Hasil Penelitian

1. Konstruksi Penelitian ini bertujuan untuk mengetahui konstruksi dan penyajian berita di LPP TVRI Pemberitaan LPP Jawa tengah. Sedangkan teori yang digunakan antara lain teori konstruksi realitas sosial TVRI JATENG dari Berger dan Luckman. Penelitian ini merupakan penelitian kualitatif deskriptif dengan Tentang Pemilihan menggunakan paradigma konstruktivis dengan menganalisa teks berita menggunakan Walikota Semarang analisis framing model Gamson dan Modigliani. Hasil penelitian menunjukkan bahwa LPP 2010, Simamora TVRI Jateng dalam menampilkan berita menjelang Pemilihan Walikota Semarang tahun Haposan, Tesis. $\quad$ 2010, masih cenderung merepresentasikan institusi, seperti KPU dan Panwas sehingga terkesan berfungsi sebagai media promosi instansi bersangkutan. Di sisi lain LPP TVRI kurang tertarik dengan berita-berita yang terkait dengan "rekam jejak" para calon walikota dan wakilnya.

2. Kontruksi Regulasi Penelitian ini membahas mengenai konstruksi regulasi penyiaran berdasarkan UU Penyiaran Di Era Penyiaran Nomor 32 Tahun 2002 di Era Konvergensi yang memuat pasal-pasal yang Konvergensi, Noneng dinilai sudah tidak sesuai lagi dengan perkembangan Teknologi Informasi dan Komunikasi Sumiaty, 2012, Jurnal (TIK). Paradigma yang digunakan dalam penelitian ini adalah paradigma konstruktivisme. BPPKI Bandung. Sedangkan pendekatannya adalah pendekatan kualitatif. Hasil penelitian ini menunjukkan bahwa konstruksi regulasi penyiaran di era konvergensi perlu dilakukan, di mana teknologi-teknologi yang sebelumnya terpisah semakin terintegrasi menjadi satu. Konvergensi teknologi ini dalam berbagai bentuknya telah dimanfaatkan oleh masyarakat Indonesia, seperti HP dan internet. Sementara peran KPI masih belum optimal, karena hanya bisa menegur media TV/Radio apabila melakukan pelanggaran terhadap peraturan penyiaran. Dengan demikian UU Penyiaran yang berlaku selama ini, harus segera direvisi karena sudah tidak sesuai lagi dengan perkembangan TIK. 
demikian, sifat dan kelebihan media massa telah memperbaiki kelemahan proses konstruksi sosial atas realitas yang berjalan lambat itu (Tamburaka, 2012).

Berger menyebut kondisi keberlangsungan antara yang 'subjektif" dan 'objektif ini sebagai dialektika eksternalisasiobjektifasi-internalisasi. Eksternalisasi menunjuk pada penyesuaian diri dengan dunia sosio-kultural sebagai produk manusia. Objektifasi merupakan interaksi sosial dalam dunia intersubjektif yang dilembagakan atau mengalami institusionalisasi. Sedangkan internalisasi adalah identifikasi diri individu di tengah lembaga sosial atau organisasi sosial di mana individu terlibat. Manusia dan masyarakat, dengan demikian, adalah produk sekaligus konstruksi sosial (Mufid, 2010).

\section{Konstruksi Media}

Membedah objektivitas dan realitas berita dalam siaran langsung media televisi cukup sulit. Hal ini dikarenakan ada beberapa unsur yang terkait di antaranya menyangkut kebijakan politik negara, kemampuan reporter menempatkan diri sebagai pelapor informasi (tidak subjektif), pemilihan pengambilan gambar, penuturan bahasa lisan maupun tertulis dari reporter dalam menyiarkan informasi, pemilihan materi informasi, durasi penayangan informasi, menentukan sasaran dari tayangan informasi.

Tidak berbeda jauh dengan surat kabar dan radio, terkadang reporter televisi dalam menyajikan sebuah informasi khususnya berita selalu diiringi opini laten reporter atau wartawan. Opini ini terlihat dari pemilihan kata (bahasa atau berita) dalam sebuah judul atau bodi berita (media cetak dan radio) dalam sebuah gambar berita (kamera) serta durasi berita (untuk televisi). Subjektivitas (opini) wartawan muncul sebagai salah satu upaya agar berita itu lebih komunikatif dan menarik perhatian khalayak sasaran terhadap berita sekaligus sarana melindungi diri dari kebijakan politik negara kalau itu berita politik (Kuswandi, 2008).

Dalam kaitannya dengan media massa dan berita, kaum konstruksionis memandang bahwa realitas yang ada di media massa yakni berita bukanlah realitas yang objektif, melainkan sebagai realitas yang telah dikonstruksi oleh pembuatnya yaitu wartawan dan media. Hal ini berbeda dengan pandangan positivis yang memahami bahwa realitas yang ada di media itu bersifat objektif. Pendekatan konstruksionis memiliki pandangan sendiri tentang media, wartawan, dan berita.

Sedangkan pandangan konstruksionis menilainya berbeda. Khalayak bukan dilihat sebagai subjek yang pasif. Ia juga subjek yang aktif dalam menafsirkan apa yang dia baca. Menurut Hall, makna dari suatu teks bukan terdapat dalam pesan/berita yang dibaca oleh pembaca. Makna selalu potensial memunyai banyak arti (polisemi). Makna lebih tepat dipahami bukan sebagai suatu transmisi (penyebaran) dari pembuat berita ke pembaca. Ia lebih tepat dipahami sebagai suatu praktik penandaan. Karenanya, setiap orang bisa memunyai pemaknaan yang berbeda atas teks yang sama (Hidayat, 2003).

\section{Berita}

Berita adalah terminologi dalam ilmu jurnalistik yang pengertian atau batasannya sebagai berikut: "News is the timely report of fact or opinion, to hold interestor importance, or both, for a considerable number of people". "Berita adalah uraian tentang peristiwa/fakta dan atau pendapat, yang mengandung nilai berita, dan yang sudah disajikan melalui media massa periodik" (Charnley dalam Wahyudi, 1996).

Menurut Guru Besar Komunikasi UI, Ibnu Hamad, berita adalah sebuah discourse (wacana). Berita yang ada sekarang adalah sebuah konstruksi realitas, bukan realitas yang sebenarnya. Discourse yang dipaparkan di dalamnya memiliki beberapa tataran antara lain, framing, signing, priming (Hamad, 2010).

Dari beberapa pengertian berita di atas, hanya pengertian yang disusun oleh Charnley yang paling lengkap. Dari pengertian ini dapat diketahui bahwa berita bukanlah peristiwa/fakta dan atau pendapat, melainkan uraiannya yang sudah disajikan melalui media massa periodik. Semua berita adalah informasi, tapi tidak semua informasi 
adalah berita, karena berita adalah informasi yang mengandung nilai berita yang telah diolah sesuai dengan kaidah-kaidah yang ada pada ilmu jurnalistik, dan yang sudah disajikan kepada khalayak melalui media massa periodik, baik cetak maupun elektronik.

Realitas di tengah masyarakat, seperti peristiwa, pendapat, masalah hangat, dan masalah unik akan menghasilkan fakta, dan hanya uraian fakta yang mengandung nilai berita serta yang sudah disajikan melalui media massa periodik yang dapat disebut sebagai berita (Wahyudi, 1996).

\section{Stasiun Televisi Lokal}

Dengan berlakunya UU No. 32 Tahun 2002 tentang Penyiaran, izin penyiaran siaran televisi lokal melalui antena UHF/VHF. UU tersebut hanya berlaku untuk stasiun televisi lokal yang ingin menyelenggarakan siaran lokal, sehingga dengan adanya UU tersebut banyak bermunculan siaran televisi lokal yang dapat dinikmati oleh masyarakat pada daerah tersebut secara gratis.

Stasiun televisi lokal di Jawa Barat telah banyak berdiri, hampir di setiap daerah tingkat kabupaten/kota sudah ada televisi lokalnya.

Dalam kontruksi realitas penyiaran pada televisi lokal dibagi tiga yaitu objective reality, symbolic reality dan subjective reality. Sementara proses konstruksinya, jika dilihat dari perspektif teori Berger dan Luckman berlangsung dalam suatu proses dengan tiga momen simultan, eksternalisasi, objektifikasi, dan internalisasi. (Hidayat, 2003). Model konstruksi dari Berger dan Luckman terlihat pada gambar 1 .

\section{METODE PENELITIAN}

Metode yang digunakan dalam penelitian ini adalah metode penelitian kualitatif melalui pendekatan konstruktivisme. Dengan menggunakan pendekatan kualitatif diharapkan dapat diperoleh pemahaman yang mendasar (verstehen) terhadap masalah-masalah sosial secara holistik dan impresif dengan menggabungkan analisis dan interpretasi data yang ditampilkan secara naratif. Hal ini sejalan dengan pendapat Creswell menyatakan bahwa pendekatan kualitatif merupakan sebuah proses penyelidikan untuk memahami masalah sosial atau masalah manusia berdasarkan pada penciptaan gambaran holistik lengkap yang dibentuk dengan kata-kata, melaporkan pandangan informan secara terperinci dan disusun dalam sebuah latar alamiah (Creswell, 2002).

Penelitian kualitatif dilakukan untuk menemukan gambaran yang menyeluruh dan mendalam tentang objek yang diteliti, dengan berangkat dari suatu fenomena yang ada, penelitian ini juga tidak berangkat dari suatu teori yang hendak diuji kebenarannya (Alwasilah, 2005).

Menurut Nasution dalam Sugiyono (2005), penelitian dilakukan sendiri oleh penulis, karena penulis merupakan instrumen utama (instrumen tunggal) dalam penelitian. Pengumpulan data dilakukan dengan wawancara mendalam. Dalam data kualitatif, dilakukan wawancara mendalam yang dipandu langsung oleh peneliti terhadap para informan yang sengaja dipilih.

Populasi dalam penelitian ini adalah para pengelola stasiun televisi lokal ATV Andalan Utama Televisi Sukabumi, baik pemimpin perusahaan maupun pemimpin redaksi, wartawan, dan petugas televisi lokal lainnya. Subjek penelitian adalah: pemimpin redaksi, koordinator liputan, presenter warta, finance dan human resources development, dan master of ceremony room. Objek penelitiannya adalah proses komunikasi yang terjadi antara peliput berita (wartawan) dan koordinator liputan dengan pemimpin redaksi, serta petugas televisi lokal yang bertugas untuk mengedit sebuah hasil liputan berita, sampai naskah berita itu layak untuk ditayangkan oleh presenter warta.

Penentuan informan ditentukan secara purposif. Teknik analisis data dilakukan dengan dianalisis secara deskriptif kualitatif, lalu disajikan dalam bentuk naratif. 


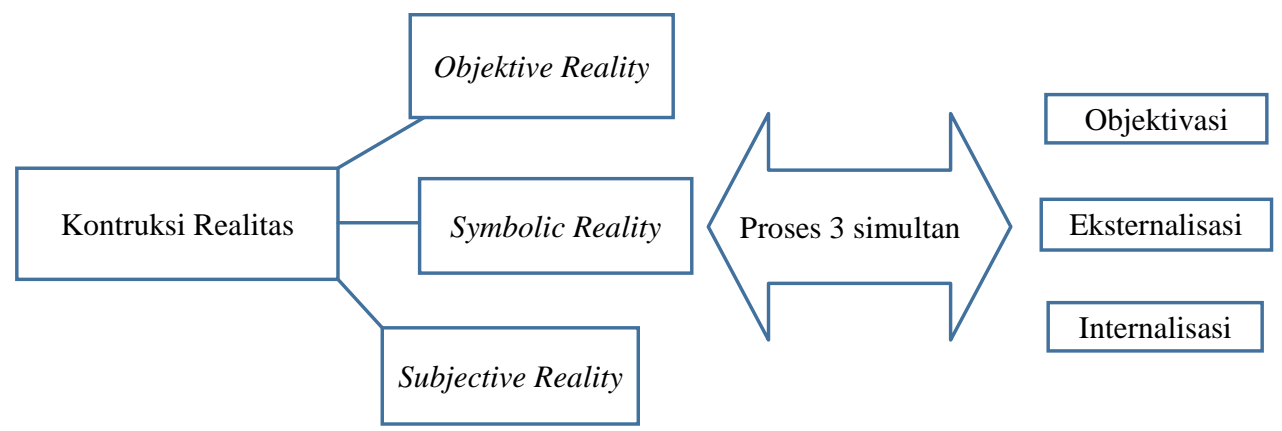

Gambar 1

Model Konstruksi dari Berger dan Luckmann

Tabel 2

Profil Informan

\begin{tabular}{ccccc}
\hline No & Nama & Jabatan & Nomor HP & Alamat \\
\hline 1 & S K & Pemimpin Redaksi & 0856xxx & Sukabumi \\
2 & D R & Koordinator Liputan & $0857 x x x$ & Sukabumi \\
3 & S N & Presenter Warta & $0858 x x x$ & Sukabumi \\
4 & R N & Finance dan HRD & $0858 x x x$ & Sukabumi \\
5 & H S & Master Control Room & $0857 x x x$ & Sukabumi \\
\hline
\end{tabular}

Sumber : Hasil Penelitian Juni 2014.

\section{HASIL PENELITIAN DAN PEMBAHASAN}

Penelitian ini dilaksanakan di stasiun televisi lokal ATV Sukabumi, informan dari pengelola televisi yang berjumlah 5 (lima) orang, yakni pemimpin redaksi, koordinator liputan, presenter warta, finance dan HRD, master control room. Data tentang informan tersaji dalam tabel 2.

Apabila dilihat dari kepemilikan media berdasarkan UU Penyiaran, menurut SK Pimpinan Redaksi (Pemred) ATV Sukabumi, menyatakan masih sesuai. Namun ada pasal yang sudah tidak sesuai lagi dengan perkembangan saat ini, misalnya pasal 18 ayat 1 dan ayat 2. Selanjutnya dikatakan "Kepemilikan tidak harus berada pada satu orang atau satu badan hukum. Kepemilikan silang harus ditinjau ulang".

\section{Konstruksi Media}

Hasil wawancara dengan informan yang berkompeten di bidang siaran berita televisi lokal ATV Sukabumi mengenai symbolic reality (teks produk industri media seperti berita). SK yang menjabat sebagai Pemred ATV Sukabumi mengatakan bahwa: "Teks produksi berita yang terjadi saat ini di televisi lokal masih terkontrol. Sementara teks produksi film ada kecenderungan bombastis dan vulgar. Sedangkan produk media tentang film di televisi lokal tidak terkontrol" (Wawancara di kantor ATV Sukabumi, Juni 2014).

Sementara bila dilihat dari subjective reality (media dan pasar), dia menyatakan bila dilihat dari media itu sendiri yang terjadi di televisi lokal saat ini bahwa televisi lokal kesulitan untuk mendapatkan sponsor khususnya di Sukabumi. Sedangkan bila dilihat dari pasar tentang media yang terjadi di televisi lokal saat ini, Sr mengatakan"Pasar media televisi lokal sangat terbatas, terutama di Sukabumi" (Wawancara dengan $\mathrm{Sr}$ di kantor ATV Sukabumi, Juni 2014).

Menurut Koordinator Peliputan ATV D $\mathrm{R}$ tentang teks produk media (berita dan film), yang terjadi saat ini di televisi lokal"Tayangan lokal terutama di daerah Sukabumi masih dinanti”. Bila dilihat dari produk media tentang berita pada televisi 
lokal menurutnya penayangan berita di televisi lokal jika dikemas dengan baik maka beritanya akan lebih menarik. Sementara bila dilihat dari produk media tentang film yang ditayangkan pada televisi lokal dia mengatakan untuk tayangan film pada televisi lokal lebih diutamakan film yang mendidik. (Wawancara di kantor ATV Sukabumi, Juni 2014).

Hasil wawancara dengan master control room ATV, SHS, tentang objective reality."Bila dilihat dari media itu sendiri, yang terjadi di televisi lokal saat ini adalah televisi lokal di mata masyarakat masih sangat awam untuk dikenal seluruh masyarakat karena jangkauannya masih sangat terbatas". Pada bagian lain dia mengatakan bahwa bila dilihat dari pasar tentang media televisi lokal pada saat ini masih stabil dan tidak mengalami penurunan. (Wawancara dengan SHS di kantor ATV Sukabumi, Juni 2014).

Bila dilihat dari objective reality (berbagai institusi sosial dalam pasar termasuk ideologi dan keyakinan) SHM mengatakan bahwa, bila dilihat dari institusi sosial dalam pasar, misalnya lembaga sosial yang ada di pasar media televisi lokal, yang terjadi saat ini sangat mendukung dengan adanya televisi lokal karena televisi lokal sebagai media perantara lembaga sosial. Tapi bila dilihat dari penayangan acara yang menyangkut ideologi dan keyakinan, dia mengatakan, "Acaranya harus disesuaikan dengan ideologi dan keyakinan yang masyarakat anut atau yang diketahui oleh masyarakat umum" (Wawancara dengan SHM di kantor ATV Sukabumi, Juni 2014).

Sementara menurut koordinator peliputan ATV DR, bila dilihat dari institusi sosial dalam pasar, misalnya lembaga sosial yang ada di pasar media televisi lokal, yang terjadi saat ini bahwa banyak lembaga sosial yang menginginkan melakukan kerjasama dalam penyampaian informasi di televisi lokal. Namun bila dilihat dari penayangan acara yang menyangkut ideologi dan keyakinan, penayangan acara religi di televisi lokal dianggap lebih baik dan mendapatkan porsi yang sesuai dengan ideologi dan keyakinan masyarakat setempat khususnya daerah Sukabumi (Wawancara dengan DR di kantor ATV Sukabumi, Juni 2014).

\section{Pembahasan}

Berdirinya televisi lokal di berbagai daerah merupakan salah satu penjabaran dari UU Nomor 32 tahun 2002 tentang Penyiaran. Begitu juga dengan televisi lokal ATV Sukabumi yang menjadi objek penelitian. Televisi lokal ATV Sukabumi menjangkau wilayah siaran seluruh Kota Sukabumi, Kabupaten Sukabumi, dan sebagian Kabupaten Cianjur.

Realitas yang ada di media massa, termasuk televisi lokal yakni berita adalah bukanlah realitas yang objektif, melainkan sebagai realitas yang telah dikonstruksi oleh pembuatnya yaitu wartawan dan media televisi lokal. Berita adalah produk dari konstruksi dan pemaknaan atas realitas. Pemaknaan seseorang atas suatu realitas bisa jadi berbeda dengan orang lain yang tentunya menghasilkan realitas yang berbeda pula.

Dalam penelitian ini kontruksi realitas penyiaran pada televisi lokal ATV Sukabumi di bagi tiga yaitu symbolic reality, subjective reality, dan objectif reality. Hasil penelitian menunjukkan bahwa secara symbolic reality, teks produksi berita yang terjadi saat ini di televisi lokal masih terkontrol. Sementara teks produksi film ada kecenderungan bombastis dan vulgar. Sedangkan produk media tentang film di televisi lokal tidak terkontrol.

Bila dilihat dari subjectiv reality (media dan pasar), bila dilihat dari media itu sendiri yang terjadi di televisi lokal saat ini bahwa televisi lokal kesulitan untuk mendapatkan sponsor khususnya di Sukabumi. Sedangkan bila dilihat dari pasar tentang media yang terjadi di televisi lokal saat ini, masih sangat terbatas, terutama di Sukabumi.

Secara objektive reality banyak lembaga sosial yang ingin melakukan kerjasama dalam penyampaian informasi di televisi lokal. Namun bila dilihat dari penayangan acara yang menyangkut ideologi dan keyakinan, penayangan acara religi di 
televisi lokal dianggap lebih baik dan mendapatkan porsi yang sesuai dengan ideologi dan keyakinan masyarakat setempat khususnya daerah Sukabumi.

Seorang jurnalis atau wartawan dalam melakukan tugasnya untuk suatu pemberitaan berawal dari rencana peliputan untuk pemberitaan, penyusunan materi berita, siapa yang akan diwawancara, lokasi yang akan diliput, dengan menerapkan rumus $5 \mathrm{~W} 1 \mathrm{H}$ (what, when, where, why, who, dan how). Dalam kenyataan di lapangan pemberitaan tidak bisa terlepas dari unsur subjektif si wartawan itu sendiri, ini terjadi pada saat wartawan mengedit naskah berita.

Televisi lokal mengonstruksi realitas dalam pemberitaan bila dilihat dari media televisi, tidak bisa terlepas dari unsur subjektif pemilik media televisi. Pemberitaan televisi lokal tidak bisa terlepas dari unsur kepentingan pemilik media televisi. Karena meskipun naskah sudah diedit oleh wartawan, namun belum bisa disiarkan jika naskah berita itu belum diedit oleh pemimpin redaksi yang secara tidak langsung merupakan wakil dari pihak yang ada kepentingan dengan pemilik media.

Proses tahapan siaran berita di ATV Sukabumi. Pertama diadakan rapat kecil rekan-rekan redaksi dengan semua wartawan yang membawahi antara lain: bidang pemerintahan kota (wartawan merangkap koordinator peliputan DR), pemerintah kabupaten (wartawan HW, dan S) serta peristiwa (wartawan P). Selanjutnya melakukan evaluasi setelah penayangan berita.

Kedua merumuskan untuk kegiatan peliputan besok. Melakukan peliputan sesuai dengan penugasan masing-masing. Misalnya reporter melakukan sesuai tugasnya, adapula yang melakukan peliputan di luar schedule (jadwal), seperti peliputan peristiwa.

Selanjutnya proses pengiriman berita dilakukan di studio, tahap awal dilakukan adalah menyerahkan gambar/vidio untuk di capture. Tahap selanjutnya membuat naskah berita. Pengeditan naskah dan proses pengeditan narasi. Setelah diedit, suara dalam bentuk file untuk dikirim ke bagian editor berita. Proses penggabungan gambar dan audio disesuaikan naskah. Setelah naskah selesai baru dilaksanakan proses pembacaan narasi.

Penyusunan
RO (roundown), dan
format presenter warta (teleponter). Kemudian persiapan pengambilan gambar presenter warta, setelah selesai baru proses capture gambar, kemudian diedit, proses pengeditan selesai, dikirim berupa file berita dan file presenter ke master control room. Setelah bahan berita diolah di bagian master control room dan siap untuk ditayangkan. Berdasarkan hal itu terlihat bahwa sebelum berita disiarkan, harus diedit oleh wartawan sebagai peliput dan oleh koordinator peliput, serta harus diedit akhir oleh pimpinan redaksi. Berarti naskah itu tidak terlepas dari subjektif wartawan dan pimpinan redaksi sebagai pengelola media televisi lokal. Itulah yang disebut berita tidak bisa bebas dari konstruksi wartawan dan media. Hal ini sesuai dengan pendapat Hamad yang mengatakan bahwa berita itu bukan sekedar menulis, memaparkan, menerapkan 5W $1 \mathrm{H}$ (what, when, where, why, who, dan how), tetapi berita itu adalah sebuah discourse (wacana). Ibnu menambahkan bahwa berita yang ada sekarang adalah sebuah konstruksi realitas, bukan realitas yang sebenarnya (Hamad, 2010).

\section{PENUTUP}

\section{Simpulan}

Sebagai lembaga penyiaran yang bergerak di penyiaran televisi lokal ATV Sukabumi dalam melaksanakan siaran berita yang disiarkan sore hari setiap harinya, merupakan hasil kerjasama antara personil kru televisi ATV Sukabumi yang berbagi tugas dalam menyelesaikan liputannya. Sehingga tersaji sebuah naskah berita yang narasinya dibacakan oleh presenter warta. Setelah peliputan selesai, dilakukan pengeditan naskah, pengeditan narasi, setelah diedit, suara dalam bentuk file untuk dikirim ke bagian edit berita. Proses penggabungan gambar dan audio disesuaikan dengan naskah. Selanjutnya penyusunan roundown, dan 
format presenter warta (teleponter). Persiapan pengambilan gambar, proses capture, kemudian diedit, dikirim file berita dan file presenter ke master control room. Setelah naskah sampai di master control room, naskah siap untuk ditayangkan.

Naskah berita yang diliput oleh wartawan merupakan hasil dari karya wartawan itu sendiri, sehingga unsur subjektif dari wartawan tidak akan hilang. Begitu juga sewaktu naskah diedit oleh koordinator liputan, pasti ada unsur subjektif yang dimasukkan terhadap naskah berita itu. Siaran berita tidak bisa terhindarkan dari unsur subjektif yang merupakan bagian dari konstruksi.

\section{Saran}

Dalam penayangan siaran berita lokal yang disiarkan setiap hari di televisi lokal ATV Sukabumi, sebaiknya jangan terlalu mengedepankan unsur kepentingan media (subjektif) baik itu yang datang dari wartawan itu sendiri atau dari koordinator peliputan dan dari pemimpin redaksi. Sehingga tidak mengurangi nilai berita itu, dan tidak ada pihak yang dirugikan.

Seandainya ada pihak yang berpesan untuk menayangkan sesuatu informasi yang berhubungan dengan kepentingan penguasa/pemerintah atau yang berkepentingan dengan lembaga tertentu atau pihak lainnya, sebaiknya pihak pimpinan redaksi atau penanggungjawab media televisi lokal ATV mempertimbangkan dengan hatihati agar nilai berita menjadi seimbang.

\section{DAFTAR PUSTAKA}

\section{Buku:}

Alwasilah, A Chaedar. (2005). Pokoknya Kualitatif. Dasar-Dasar Merancang Dan Melakukan Penelitian Kualitatif. Jakarta: Pustaka Jaya.

Bungin, Burhan. (2008). Sosiologi Komunikasi, (Teori, Paradigma, dan Diskursus Teknologi Komunikasi di
Masyarakat), Jakarta: Kencana Predana Media Group.

Cresswell, John W. (2002). Research Design Qualitative and Quantitative Approches. Desain Penelitian, Pendekatan Kualitatif dan Kuantitatif, Jakarta: Penerbit: Kil Pers.

Hidayat, Deddy. (2003). Konstruksi Sosial Industri Penyiaran. Jakarta: Pascasarjana Ilmu Komunikasi UI.

Kuswandi, Wawan. (2008). Komunikasi Massa (Analisis Interaktif Budaya Massa). Jakarta: Rineka Cipta.

Mufid, Muhamad. (2010). Komunikasi dan Regulasi Penyiaran. Jakarta: Kencana Predana Media Group.

Sugiyono. (2008). Memahami Penelitian Kualitatif. Bandung: CV. Alfabeta

Tamburaka, Apriadi. (2012). Agenda Setting Media Massa. Jakarta: PT Raja Grafindo Persada.

(2013). Literasi Media:

Cerdas Bermedia Khalayak Media Massa. Jakarta: Rajawali Pers.

Wahyudi, J.B. (1996). Dasar-Dasar Jurnalistik Radio dan Televisi. Jakarta: Pustaka Utama Grafiti.

\section{Jurnal:}

Sumiaty, Noneng. (2012). Kontruksi Regulasi Penyiaran Di Era Konvergensi, Jurnal Penelitian Komunikasi, 15

Desember. Hal. 205 - 222.

\section{Makalah:}

Hidayat, Deddy. (2003, Maret). Konstruksi Sosial Industri Penyiaran: Kerangka Teori Mengamati Pertarungan di Sektor Penyiaran, Naskah dipresentasikan dalam diskusi "UU Penyiaran, KPI dan Kebebasan Pers, di Salemba, Jakarta

\section{Internet:}

Simamora, Haposan. (2010). Konstruksi Pemberitaan LPP TVRI JATENG Tentang Pemilihan walikota Semarang 2010. Tesis, Universitas Diponegoro. Tersedia di 
<http://eprints.undip.ac.id/38384/>, diakses tanggal 18 Februari 2014.

Hamad, Ibnu. (2010). Menggugat Tanggung Jawab Etika Pemberitaan Media Masa. Jakarta. Tersedia di $<$ http://habibiecenter.or.id/detilurl/id/6 4//>, diakses tanggal 11 Maret 2014.

Institusi, Perusahaan, Atau Organisasi sebagai penulis:

Himpunan Peraturan Perundang-undangan di Bidang Penyiaran, Ditjen Sarana Komunikasi Dan Diseminasi Informasi Direktorat Usaha Penyiaran Tahun 2009, Kementerian Komunikasi Dan Informatika Republik Indonesia. 